\title{
Capitalism Penetration and Ecological Degradation in South Kalimantan: A Historical Sociology Perspective
}

\author{
Yety Rochwulaningsih ${ }^{11}$, Noor Naelil Masruroh ${ }^{1}$, Fanada Sholihah ${ }^{2}$, Sutejo K. Widodo ${ }^{1}$, and \\ Susilo Budiyanto ${ }^{3}$ \\ ${ }^{1}$ Department of History, Faculty of Humanities, Universitas Diponegoro, Semarang, Indonesia \\ ${ }^{2}$ Center for Asian Studies, Faculty of Humanities, Universitas Diponegoro, Semarang, Indonesia \\ ${ }^{3}$ Department of Agrotechnology, Faculty of Animal and Agriculture, Universitas Diponegoro, \\ Semarang, Indonesia.
}

\begin{abstract}
This article analyses the relationship between capitalism penetration and growing ecological degradation in South Kalimantan. Capitalism is manifested through excessive logging and the conversion of tropical rainforests into oil palm plantations, a practice that has been rampant since the New Order era. During the President Soeharto in office, natural resources were exploited extensively under the pretext of national development by granting forest concessions to private and state-owned companies. Continuing land clearing and concession burdens of up to 50 percent are the causes of the ecological disaster that occurred in South Kalimantan. The heavy flood phenomenon that happened in January 2021 reflects a long history of capitalism penetration on estate business rooted since the 1980s, when Forest Concession Rights holders began to intensively deforest. This fact is authoritatively opposed by some businessmen who claim that the issue of deforestation is deliberately raised as a trade policy strategy for developed countries. By using a sociological historical approach, it traces the roots of capitalism penetration and looks at to what extent of its influence to the ecological balance in South Kalimantan. Ironically, local communities also take part to strengthen the capitalism chain.
\end{abstract}

\section{Introduction}

Environmental Environmental degradation in South Kalimantan came into the spotlight after widespread floods inundated South Kalimantan on January 12-13, 2021. In the Hulu Sungai Tengah, as many as 64,000 residents were affected by flooding. According to an initial assessment, one of the leading causes of flooding was converting tropical rainforests into oil palm plantations. In the last two decades, land use and forest cover in South Kalimantan have changed drastically. Natural forest cover in Hulu Sungai Tengah stood at $78 \%$ in 2000, but during 2016 the area had been completely deforested. Land conversions have also occurred

*Corresponding author: wulan@live.undip.ac.id 
in several areas of South Kalimantan that were affected by the flooding, including Tanah Laut Regency, Balangan Regency, Tapin Regency, Banjar Baru City, and Tabalong Regency $[1]$.

In 2020, Wahana Lingkungan Hidup (Walhi) released a report on land conversions in South Kalimantan. CNN Indonesia also reported that South Kalimantan had experienced environmental degradation due to "crimes" in the natural resource sector. Of the total 3.7 hectares of land in South Kalimantan, nearly $50 \%$ is controlled by mining and oil palm companies. This has resulted in damage to the natural ecosystem in the upstream area, which initially functioned as a water catchment, which in turn causes flooding in the downstream area [2]. Furthermore, the National Aeronautics and Space Agency (Lapan) also analysed medium-resolution remote sensing satellite data. The two factors that contributed to flooding were high rainfall and dwindling primary forest land.

Meanwhile, an analysis of the Barito Watershed (DAS) indicated a decrease in forest areas. The decrease in the area of the Barito watershed is in line with the significant expansion of plantations. In 10 years, there was an expansion in plantation areas of 219,000 hectares [3]. However, the Environment and Forestry entity (LHK) denied a shrinkage in the Barito watershed in South Kalimantan, saying that floods that hit South Kalimantan were more likely to be caused by extreme rainfall and happened every 50 to 100 years, last time in 1926 . Rather than seeing this problem as a result of excessive natural exploitation, the Government of South Kalimantan is more likely to view this disaster as a weather anomaly with rainfall with an intensity of nearly 2 billion more $\mathrm{m} 3$ on 10-13 January [4].

This article aims to complement the narrative from a socio-historical perspective regarding the scale of ecological damage in South Kalimantan. To which extent the intensive penetration of capitalism began in the New Order regime, through the granting of forest concessions to private companies and state-owned companies, has had a side effect in the form of ecological degradation in South Kalimantan. By using a variety of literature and newspapers, this study seeks to identify the causes of the ecological disaster in South Kalimantan in early 2021.

Environmental degradation and its various consequences in South Kalimantan tend to be overlooked in scientific discourse. This contrasts to more exposure enjoyed by the eastern and western parts of Kalimantan among researchers, many of whom use the discussions to start a long debate. For instance, Chokkalingam and Suyanto (2004) discussed that the burning of dry land or wetlands in East Kalimantan is the most significant contributor to deforestation. The repeated fires have contributed to the loss of vegetation, which has brought severe disasters to the surrounding population, such as annual floods and silting of lakes. Land clearing using fire is believed to be closely linked to businesses interested in immediately converting land into oil palm plantations and coal mines [5]. In line with Chokkalingam and Suyanto (2004), Nooteboom and Jong (2010) observed ecological degradation in the Mahakam wetlands, East Kalimantan. External actor, such as logging and mining companies and oil palm plantations, is considered responsible for this condition. In this situation, local communities are powerless to resist the expansion of outside actors due to several factors, one of which is quite prominent is the collaboration between local brokers and foreign companies [6]. Ironically, it is common for local farmers to also play a role in strengthening the chain of capitalism by expanding palm oil plantations on land they owned around their homes [7].

In contrast to the communities in East Kalimantan, who tend to be passive in facing the influx of foreign investors, Yuliani et al. [8] looked into the active participation of local communities in Kapuas Hulu District, West Kalimantan. They are considered successful in protecting the forest from the threat of illegal logging and forest conversion into oil palm plantations. This community resistance is rooted in eudaimonia motivation, namely the desire to live meaningfully and in harmony with nature. Long-term economic thinking mixed with 
the idea that nature is a legacy from our ancestors has become a vital bulwark for all efforts to exploit nature [9]. This gives a clear picture that people have local wisdom. in natural resource management. However, at a certain point, local wisdom is deliberately "turned off" because it is against the interests of the capitalists. In turn, the domination of the state ridden by the hands of capitalists in the management of natural resources tends to ignore the interests of local communities [10].

Yulian et al. (2017) provide an overview of the socio-economic impacts of oil palm plantation expansion on rural household livelihood systems in East Kalimantan. Even though oil palm plantations seem to improve the welfare of rural households, the fact that has been overlooked is the vulnerability and high dependency of livelihoods on income from oil palm plantation wages. The oil palm business often leads to a dilemma, especially for ecological balance. The pressure of global market demand and the need to spur national economic growth are often the driving factors for the massive expansion of oil palm plantations in Indonesia. Although they provide benefits economically, oil palm plantations also come with social and environmental impacts, including changes in agrarian structure, land disputes, disruptions to rural household livelihood systems, reduced biodiversity, mono-crop culture and deforestation [11].

Preliminary studies related to the clearing and use of wetlands in South Kalimantan have been conducted by Rochwulaningsih et al. (2020). The opening of paddy fields, which was initially intended to expand the area of food crops as part of government policy on food selfsufficiency, has dramatically transformed into a capitalist medium. Land clearing was integrated with the transmigration program that began in the 1960s. However, the expansion of lowland use causes two fundamental environmental management problems: the large volume of submerging water and the relatively high level of acidity. The massive expansion of capitalism emerged and developed in plantations in wetlands, such as oil palm plantations. To curb the trend, the government imposed a moratorium on plantation activities in wetlands for oil palm plantations to improve the management of plantation land and preserve the environment. The moratorium also applies specifically to oil palm plantations [12].

What has been happened in South Kalimantan reflected on the severe environmental crisis as global capitalism arouse to contribute deforestation and ecological damage. The capitalist model of the society has been failing and generates public worries over the well-being of ecology under unlimited exploitation by capitalist activities. The worries also support Bogg [13] that environmental crisis has a new perspective of viewing not only economic development but also political governance, culture, nature, and social changes. The environmental crises also reflect the expanding productive capacity that had taken place since colonialism [14]. The problems had emerged about the relationship between capitalism and ecological damage in South Kalimantan and the factors that support the damage. In addition, this issue had not been appropriately responded during the decades due to the controversy over the forest management rights, which worsened it.

\section{Method}

This research employs a critical historical method that emphasises sources exploration, criticism, interpretation, and historical writing. Primary sources in the form of newspaper publications published in the period 1970's and 2000's, such as The Strait Times, Arizona Republic, Kompas, and other newspapers published nationally and internationally, have been used to analyse and answer the research problems. Corroboration has been used to compare factual information contained in the sources. Besides primary sources, this study also 
examines secondary sources in books, scientific articles, videos, and magazines. It then corroborates into one another until reaching the interpretation or hypothesis.

\section{Results and Discussion}

On the practical level, capitalism has never been compatible with ecocentrism, as is the economics case, between the public and the producers. Within this framework, conflicts between macro-interests and micro-interests often occur, such as the desire to foster a clean environment for the general public and the interests of managing factories at minimum costs. There are always conflicts between long-term and short-term interests, such as seeking logging and replanting [15].

According to Emil Salim, environmental issues are riddled with conflicting interests. This conflict of interest occurs between the party affected by environmental pollution and the party causing the pollution. A plantation company produces sufficient materials, accommodates labour, and generates significant taxes for the region so that the micro-economic benefits of the company can be assessed. However, these plantation companies also destroy the environment and destroy the only ecosystem that affects the totality of flora and fauna life. Even not only in the region but for the whole country [15].

Capitalism is a system that places the obsession with growth and profit accumulation at the core of all its activities. Magdoff and Foster [16], two scientists and activists on ecological issues, believe that the root of the problem of environmental degradation comes from the economic system adopted. The two of them then recommended a way out, which was quite extreme in the form of disconnecting oneself from the system, which was based on the motive of continuous capital accumulation. This break is a necessary condition for the creation of a new ecological civilization. Both of them considered that small individual efforts to reduce environmental degradation proved ineffective. This is evidenced by the continuation of increasingly severe ecological degradation [16]. For example, expansion of oil palm plantations in forest areas has logical consequences in the form of reduced forest area and groundwater quality [7], [17], deforestation [18], habitat fragmentation, and loss of biodiversity [7].

In some cases, capitalists do not hesitate to cut through the carrying capacity of nature, thus leading to more severe natural disasters. They are considered exposed to a symptom of human "childless" [10], assuming that natural resources are unlimited. As a result, environmental damage occurring in Indonesia shows an increasing trend. Although the conception of development has been a discussion that has drawn criticism because it always comes down to the economic dimension, the economic aspect is still the most dominant in measuring the success of a country's development [10].

\subsection{Controversy over Forest Management Rights (HPH): Conservation or Trade Politics?}

Kalimantan is the size of France, and its terrain features forests and hills. In 1957, as much as 74 per cent of Indonesia's forests were in Kalimantan and the eastern part of Indonesia, covering 240,000 hectares, about two-thirds of the total land area. Meanwhile, 24 per cent were in Sumatra and 2 per cent in Java and Madura [19]. Most of the forest consists of a variety of plantations. This often results in high-cost logging operations. Several kinds of wood are commonly exported, including rattan, resin, tannin barks, teak, and wood for construction purposes [19]. Kalimantan wood is also directed to supply the paper industry. Although before implementing the Five Years Development (Pelita) I, the forestry sector did not contribute significantly to development, during the 1968-1978 period, the role of forestry 
jumped sharply, even occupying the second position after oil in the value of Indonesian exports. Meanwhile, in the international timber market, prices have begun to improve; this is also in line with conditions in Indonesia. Domestically, the demand for wood is increasing, driven by the need to build housing, plywood, and other wood processing industries [15].

In terms of quantity, there is a trend of increasing foreign demand for timber. During Pelita I (1969), Indonesia's wood production was only at 8.1 million cubic meters. However, during Pelita II, it jumped to 22.4 million cubic meters (1977), and even in 1973, it reached a production peak of 25.8 million cubic meters. This was partly attributed to housing development programs in Japan and the United States and plywood factories and sawmills in South Korea and Taiwan [15]. In April 1978, 693 businesses covered 73 million hectares with a total investment of US \$ 1.3 billion and Rp 500 million. In addition, there were forest exploitation permits issued by local governments, the number and size of which were not precisely known [15].

Local government permits led to more massive forest exploitation. Local governments had an interest in increasing revenue and failed to consider the conditions for technically responsible forest exploitation. The cubic permit issued by the local government resulted in forest exploitation methods that practically destroyed forest sustainability. Furthermore, in Repelita III (1979-1984), the development direction was focused on labour-intensive industries to increase exports. Therefore, the government optimized the use of wood in several forest areas, including in Kalimantan, Sumatra, Sulawesi and Papua. Low-quality timber was used to meet domestic needs, while superior quality was exported [20]. Kalimantan timber was also absorbed by paper manufacturing companies. In fact, in 1981, Indonesia had a paper and pulp production project with a target of 1.5 million tons each year. Twenty-eight small-scale paper manufacturing companies produced 215,000 tonnes of paper, or about half of Indonesia's consumption of 430,000 tonnes. In 1982, South Kalimantan produced 20,0000 tonnes of bleached kraft paper and 147,000 tonnes of fine paper annually [21].

The high demand for timber on the international market has undoubtedly led to more logging activities carried out by capital owners. At a certain point, continuous industrial activity will gradually reduce the natural carrying capacity of the environment to absorb the industry's negative influence on the environment. However, conspiracies were developed. It is said that, in order to safeguard the economy and to increase capital accumulation consistently, the capitalists often display a pro-environmental image. This is pursued in various ways by financing research that confirms that natural degradation is not caused by human activity but rather by the natural transformation of nature itself [15].

According to the reports, tropical forest destruction is the leading cause of global warming. The depletion of biodiversity was often motivated by trade politics to discourage developing countries that are home to tropical forests from exploiting the resources for their economic development. They claimed that forest concession holders had sustainably managed the forest, in addition to seeking to improve the standard of living of local communities and not the other way around. The claim is also accompanied by quantitative data regarding the amount of forest that has been used by HPH holders that Indonesia has only cut forests of less than 0.2 cubic meters/year/ha. Indonesia's forest area is $143 \mathrm{ha}$, only 30 million cubic meters of wood are cut every year.

Meanwhile, forests in the Midwest have been converted into soybean fields and forests in the United States (US) into cotton fields. The US also experiences many environmental problems, such as forest fires and floods that occur every year. Likewise, in Australia, most of its territory is red soil without trees. Therefore, forest rights holders contend that the attacks by developed countries were due to concerns that Indonesia would become a strong competitor in international trade. This indication can be seen from the imposition of import 
duty of as much as 8.2 per cent on Indonesia's plywood exports to the US, as opposed to 4 per cent for Brazil and zero for the Philippines and Malaysia [22].

The ecological disaster in South Kalimantan, allegedly caused by deforestation, has long historical roots; for example, on January 7, 1981, the provincial roads in Tanah Laut, South Kalimantan, were inundated. One of the causes was deforestation by forest concession holders (HPH). The Public Works Agency explained that the water that flooded the road was caused by the overflow of the Sawarangan River, which is located at 99-kilo meters. A similar flood had also occurred in 1981. The overflow of the Sawarangan River was attributed to deforestation in the upper reaches of the river. Deforestation was the result of mechanical logging by HPH holders. Although it is recognized that deforestation by local people exists, it is in tiny amounts [23].

\subsection{Ecological Degradation Caused by Palm Oil Plantation Expansion}

The expansion of oil palm plantations in Indonesia is a variable that is quite influential in transforming or changing the ecological landscape and land use. For example, changes in land cover, land use, deforestation, and loss of biodiversity [24]. The majority of businesses are not unaware of the seriousness of environmental problems caused by their industrial activities. However, various compensation measures will increase company costs so that they impact reducing the company's competitive ability [15].

The danger arising from the operation of palm oil mills comes from the disposal of its waste, which severely pollutes water. Palm oil waste cannot be processed completely. Waste directly disposed of into rivers or waters will harm the environment such as turbidity, silting, depletion of oxygen dissolved in water. It disrupts and even kills aquatic life [25]. In 1990, 84 palm oil mills (PKS) units had a processing capacity between 10-60 tonnes of fresh fruit bunches (FFB) per hour. During 1990, it is estimated that PKS has processed 12.6 million tons of FFB, and liquid waste disposed of into the water is 70 per cent of processed FFB, which is as much as 8.82 million cubic meters a year. PKS liquid waste contains compound and inorganic materials that can pollute the environment, with acidity levels $(\mathrm{pH})$ between 4.0-4.6, floating solids $15,000-40,000 \mathrm{mg} / \mathrm{liter}$, dissolved solids $15,000-30,000 \mathrm{mg} / \mathrm{liter}$, oil $6,000-15,000 \mathrm{mg} /$ liter, nitrogen $500-900 \mathrm{mg} /$ liter, biochemical oxygen requirement (BOD) 20,000-40,000 mg/liter, chemical oxygen requirement (COD) 40,000-80,000 mg/liter [25].

Theoretically, corporate economics has developed a shadow pricing system to assess costs incurred by industry to society, which is known as 'social cost pricing'. Therefore, the impact of environmental damage can be calculated through this social price calculation system. However, in its implementation, this kind of practice is considered too expensive for the industry's survival, leading many companies to ignore the environmental impact of their industrial activity [23].

Global palm oil production has continued to increase from 1960 to the present in line with growing global demand for CPO-Crude Palm Oil) [24]. Palm oil in Southeast Asia, especially in Indonesia and Malaysia, contributes to foreign exchange earnings and national economic growth for the two countries. According to the Indonesian Ministry of Agriculture, oil palm is a plantation commodity that ranks first in the land area compared to other plantation crops in Indonesia (Indonesian Ministry of Agriculture, 2015). As the number of oil palm plantations in Indonesia continues to grow, Malaysia remains Indonesia's main competitor in the industry. In 1991, Malaysia produced 6.1 million palm oils, equivalent to 57 per cent of palm oil production. Exports of palm oil and similar production generate foreign exchange of around US\$2.07 billion, with the primary market being China, Singapore and Pakistan. The Minister of Primary Industry of Malaysia, Lim Keng Yaik, led the palm oil delegation which was at the same time seeking importers from Brazil, Venezuela and Mexico. 
Compared to Malaysia, the mechanization technology for palm oil mill plantations in Indonesia has been lagging. The design and processing of palm oil (CPO-crude palm oil) imitate CPO factories in Malaysia from 1966. As a result, processing costs are very high, and the quality is low. As a result, the processing process is incomplete, resulting in low-quality palm oil, high in free fatty acids (FFA-free fatty acids). Meanwhile, factories in Malaysia are already using advanced technology to improve the quality of palm oil and reduce processing costs. Consequently, although Indonesia can produce fresh fruit bunches (FFB) for palm oil at low prices, the cost jump they are converted to CPO. On the other hand, FFB is produced at a high price in Malaysia, but the CPO is relatively cheap [26].

\section{Conclusions}

At least two significant issues have been addressed as factors to worsen the environmental crisis in South Kalimantan global capitalism and low-level of regulation since the New Order regime and up until now. Penetration of capitalism has been represented by the industrial operations on the palm oil business and the controversial regulations of the forest management holders (HPH). Concession holders should reflect and examine the scale of damage caused by excessive industrial activity. They then identify the steps that need to be taken in the face of future challenges to build a healthy industry in a fair environment.

\section{Acknowledgement}

This research and publication have been funded by Institute for Research and Community Service Universitas Diponegoro (Research for International Publication Higher Reputation) 2021 under the scheme of Research for International Publication Higher Reputation.

\section{References}

[1] "7 Kabupaten Terendam, Ini Update Banjir yang Lumpuhkan Kalsel." https://www.cnbcindonesia.com/news/20210116191423-4-216588/7-kabupatenterendam-ini-update-banjir-yang-lumpuhkan-kalsel (accessed May 30, 2021).

[2] "Banjir Kalsel, Walhi Ingatkan soal Kerusakan Lingkungan." https://www.cnnindonesia.com/nasional/20210116102955-20-594505/banjir-kalselwalhi-ingatkan-soal-kerusakan-lingkungan (accessed May 30, 2021).

[3] "Teka-teki Penyebab Banjir Besar di Kalimantan Selatan Halaman all. Kompas.com.” https://nasional.kompas.com/read/2021/01/21/08535951/teka-tekipenyebab-banjir-besar-di-kalimantan-selatan?page=all. (acces May 30, 2021).

[4] "Dikepung Bencana: Banjir Akibat Kerusakan Alam di Kalimantan Selatan? (Part 6)." https://www.youtube.com/watch? v=cOhxsOzqNho (accessed May 30, 2021).

[5] U. Chokkalingam and Suyanto, "Fire, livelihoods and environmental degradation in the wetlands of Indonesia: A vicious cycle," Center for International Forestry Research, 2004. Accessed: May 30, 2021. [Online]. Available: https://www.jstor.org/stable/resrep01996

[6] E. B. P. de Jong and G. Nooteboom, “Against 'Green Development Fantasies': Resource Degradation and the Lack of Community Resistance in the Middle Mahakam Wetlands, East Kalimantan, Indonesia in: Volume 38 Issue 2 (2010)," Asian J. Soc. Sci., vol. 38, no. 2, pp. 258-278, 2010.

[7] R. Amalia, A. H. Dharmawan, L. B. Prasetyo, and P. Pacheco, "Perubahan Tutupan Lahan Akibat Ekspansi Perkebunan Kelapa Sawit: Dampak Sosial, Ekonomi dan 
Ekologi," J. Ilmu Lingkung., vol. 17, no. 1, Art. no. 1, May 2019, doi: 10.14710/jil.17.1.130-139.

[8] E. L. Yuliani, E. B. P. de Jong, L. Knippenberg, D. O. Bakara, M. A. Salim, and T. Sunderland, 'Keeping the land: Indigenous communities' struggle over land use and sustainable forest management in Kalimantan, Indonesia," Ecol. Soc., vol. 23, no. 4, 2018, doi: 10.5751/ES-10640-230449.

[9] E. L. Yuliani, E. B. P. de Jong, L. Knippenberg, D. O. Bakara, M. A. Salim, and T. Sunderland, "Keeping the land: Indigenous communities' struggle over land use and sustainable forest management in Kalimantan, Indonesia," Ecol. Soc., vol. 23, no. 4, 2018, doi: 10.5751/ES-10640-230449.

[10] O. S. Abdoellah, Pembangunan Berkelanjutan di Indonesia: Di Persimpangan Jalan. Gramedia Pustaka Utama, 2016.

[11] B. E. Yulian, A. H. Dharmawan, E. Soetarto, and P. Pacheco, "Livelihood Dilemma of The Rural Household Around the Oil Palm Plantation in East Kalimantan," Sodality J. Sosiol. Pedesaan, vol. 5, no. 3, Art. no. 3, 2017, doi: 10.22500/sodality.v5i3.19398.

[12] Y. Rochwulaningsih, N. N. Masruroh, F. Sholihah, S. K. Widodo, and S. Budiyanto, "Managing Socio-Economic Problems of the Wetland Environment in South Kalimantan," E3S Web Conf., vol. 202, p. 03025, 2020, doi: 10.1051/e3sconf/202020203025.

[13] C. Bogs, Ecology and Revolution: Global Crisis and the Political Challenge. New York: Palgrave Macmillan, 2012.

[14] M. G. Meniketti, Sugar Cane Capitalism and Environmental Transformation: An Archaeology of Colonial Nevis, West Indies. Alabama: University of Alabama Press, 2015.

[15] E. Salim, Lingkungan Hidup dan Pembangunan. Jakarta: Penerbit Mutiara, 1980.

[16] F. Magdoff and J. B. Foster, Lingkungan Hidup dan Kapitalisme: Sebuah Pengantar. Yogyakarta: Margin Kiri, 2018.

[17] "Silang sengkarut pengelolaan hutan dan lahan di Indonesia." [Online]. Available: https://fwi.or.id/wp-content/uploads/2017/12/executivesummary8des17_final.pdf

[18] E. N. Setiawan, A. Maryudi, R. H. Purwanto, and G. Lele, "Opposing interests in the legalization of non-procedural forest conversion to oil palm in Central Kalimantan, Indonesia - ScienceDirect," Land Use Policy, vol. 58, pp. 472-481, 2016.

[19] "Many Forest in Indonesia," Arizona Republic, p. 53, Feb. 28, 1957.

[20] "A slight but significant shift in the nation's development policy," The Straits Times, Aug. 13, 1978.

[21] “Asean's paper output will be insufficient,” Business Times, Jan. 01, 1982.

[22] “Isu Kerusakan Hutan Tropis Acap Bermotif Politik Dagang," Kompas, Aug. 31, 1993.

[23] "Akibat Penggundulan Hutan oleh Pemilik HPH: Jalan Propinsi di Tanah Laut Digenangi Banjir," Jan. 13, 1981.

[24] E. Yuliani, E. de Jong, L. Knippenberg, D. Bakara, M. Salim, and T. Sunderland, "Keeping the land: indigenous communities' struggle over land use and sustainable forest management in Kalimantan, Indonesia," Ecol. Soc., vol. 23, no. 4, Dec. 2018, doi: 10.5751/ES-10640-230449.

[25] "Limbah Pabrik Kelapa Sawit, Banyak Mencemari Lingkungan," Kompas, Jun. 21, 1991.

[26] “Pabrik CPO Indonesia Sudah Ketinggalan Zaman,” Kompas, Agustus 1991. 